\title{
Reduced magnitude and durability of humoral immune responses by COVID-19 mRNA vaccines among older adults
}

Mark A. Brockman ${ }^{1,2,3, \#, *}$, Francis Mwimanzi ${ }^{1}$, Hope R. Lapointe ${ }^{3}$, Yurou Sang ${ }^{1}$, Olga Agafitei ${ }^{1}$, Peter Cheung ${ }^{1,3}$, Siobhan Ennis ${ }^{1}$, Kurtis $\mathrm{Ng}^{1}$, Simran Basra ${ }^{1,2,4}$, Li Yi Lim ${ }^{1,2}$, Fatima Yaseen ${ }^{2}$, Landon Young $^{5}$, Gisele Umviligihozo ${ }^{1}$, F. Harrison Omondi ${ }^{1,3}$, Rebecca Kalikawe ${ }^{1}$, Laura

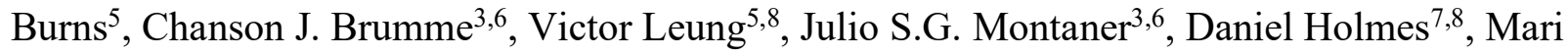
DeMarco $^{7,8}$, Janet Simons ${ }^{7,8}$, Ralph Pantophlet ${ }^{1,2}$, Masahiro Niikura ${ }^{1}$, Marc G. Romney ${ }^{5,8, \#, *}$, Zabrina L. Brumme

${ }^{1}$ Faculty of Health Sciences, Simon Fraser University, Burnaby BC, Canada;

${ }^{2}$ Department of Molecular Biology and Biochemistry, Simon Fraser University, Burnaby BC, Canada;

${ }^{3}$ British Columbia Centre for Excellence in HIV/AIDS, Vancouver BC, Canada;

${ }^{4}$ Department of Chemistry, Simon Fraser University, Burnaby BC, Canada;

${ }^{5}$ Division of Medical Microbiology and Virology, St. Paul's Hospital, Vancouver BC, Canada;

${ }^{6}$ Department of Medicine, University of British Columbia, Vancouver BC, Canada;

${ }^{7}$ Division of Medical Biochemistry, St. Paul's Hospital, Vancouver BC, Canada;

${ }^{8}$ Department of Pathology and Laboratory Medicine, University of British Columbia, Vancouver BC, Canada

*equal contribution

\# Address correspondence to: MAB (mark_brockman@sfu.ca); MGR (mromney@providencehealth.bc.ca); or ZLB (zbrumme@sfu.ca) 


\begin{abstract}
Background. mRNA vaccines reduce COVID-19 incidence and severity, but the durability of vaccine-induced immune responses, particularly among the elderly, remains incompletely characterized.
\end{abstract}

Methods. Anti-spike RBD antibody titers, ACE2 competition and virus neutralizing activities were longitudinally assessed in 151 healthcare workers and older adults (overall aged 24-98 years) up to three months after vaccination.

Results. Older adults exhibited lower antibody responses after one and two vaccine doses for all measures. In multivariable analyses correcting for sociodemographic, chronic health and vaccine-related variables, age remained independently associated with all response outcomes. The number of chronic health conditions was additionally associated with lower binding antibody responses after two doses, and male sex with lower ACE2 competition activity after one dose. Responses waned universally at three months after the second dose, but binding antibodies, ACE2 competition and neutralizing activities remained significantly lower with age. Older adults also displayed reduced ability to block ACE2 binding by the Delta variant. Conclusions. The humoral immune response to COVID-19 mRNA vaccines is significantly weaker with age, and universally wanes over time. This will likely reduce antibody-mediated protection against SARS-CoV-2 and the Delta variant as the pandemic progresses. Older adults may benefit from additional immunizations as a priority. 


\section{INTRODUCTION}

Older age is the greatest risk factor for lethal coronavirus disease 2019 (COVID-19) following infection with severe acute respiratory syndrome coronavirus 2 (SARS-CoV-2) ${ }^{1-3}$. While COVID-19 vaccines offer hope to end the pandemic ${ }^{4-7}$, "real world" assessments have revealed weaker vaccine-induced immune responses in certain groups including the elderly ${ }^{8-13}$, though few studies have adjusted for potential confounders, including comorbidities, that can accumulate with age. Vaccine response durability also remains incompletely characterized, as immunogenicity assessments are occurring concomitantly with national vaccine rollouts.

Two mRNA vaccines, BNT162b2 (Pfizer/BioNTech) and mRNA-1273 (Moderna), have been administered widely in North America and Europe. While both provided $>94 \%$ protection against moderate or severe COVID-19 in clinical trials after two doses ${ }^{6,7}$, and while population-level reductions in COVID-19 were clearly observed following initial vaccine rollouts, ongoing outbreaks in long-term care facilities underscore the continuing vulnerability of older adults to SARS-CoV-2 infection, even after vaccination ${ }^{14}$. Longitudinal assessments of the magnitude and durability of vaccine-induced immune responses can inform public health decision-making for older adults as the pandemic progresses. However, while age and ageassociated comorbidities, including chronic health conditions that can result in immune dysregulation, have been linked to poor vaccine immune responses ${ }^{15-17}$, few studies have explored these variables in the context of COVID-19 immunization.

We investigated the magnitude of SARS-CoV-2-specific humoral immune responses after one and two mRNA vaccine doses in 151 participants aged 24-98 years. In a subset of participants with specimens available at time of writing, we further examined response durability three months following the second vaccine dose, including against the widely circulating Delta 
variant (B.1.617.2). Our results demonstrate weaker humoral responses to COVID-19 mRNA vaccines in older versus younger adults, signified by lower magnitude and durability of spikespecific binding and neutralizing antibody activities even after correction for potential confounders, and potentially reduced neutralization of the Delta variant.

\section{METHODS}

Study design. We conducted a prospective longitudinal cohort study in British Columbia, Canada, to examine SARS-CoV-2 specific humoral immune responses following COVID-19 mRNA vaccination. The cohort, totaling 151 individuals, comprised 89 healthcare workers and 62 older adults (including 23 residents of long-term care and assisted living facilities, and 39 seniors living independently).

Ethics approval. Written informed consent was obtained from all participants or their authorized substitute decision makers. This study was approved by the University of British Columbia/Providence Health Care and Simon Fraser University Research Ethics Boards (protocol H20-03906).

Participants and sampling. Participants were recruited at facilities operated by Providence Health Care (Vancouver) and the community. Serum and plasma were collected prior to vaccination, one month after the first dose, and at one and three months after the second dose. Specimens were processed same-day and frozen until analysis. COVID-19 convalescent individuals were identified at study entry by the presence of serum antibodies recognizing SARS-CoV-2 nucleoprotein (N). 
Data sources and immunity measures. Sociodemographic data (age, sex, ethnicity), chronic health conditions and COVID-19 vaccination information were collected by self-report and confirmed through medical records where available. Chronic health conditions were defined as hypertension, diabetes, chronic diseases of lung, liver, kidney, heart or blood, cancer and immunosuppressive conditions/drugs to create a numerical variable ( $0-9$ conditions) per participant. Vaccine-induced antibody responses against SARS-CoV-2 were assessed three ways: (1) Commercial and in-house assays to detect binding antibodies targeting the spike receptor binding domain (RBD); (2) Angiotensin-converting enzyme 2 (ACE2) competition assays to detect receptor-blocking antibodies; and (3) Neutralization assays to detect antibodies that prevent virus infection of target cells.

Binding antibody assays. We examined total binding antibodies against the SARS-CoV-2 N and RBD in serum using the Elecsys Anti-SARS-CoV-2 assay (which detects anti-N antibodies generated following infection) and Anti-SARS-CoV-2 S assay (which quantifies total antibodies against RBD generated following infection or vaccination), respectively, on a Cobas e601 module analyzer (Roche Diagnostics). Both assays incorporate sandwich ELISA and electrochemiluminescence detection and report results in arbitrary units $/ \mathrm{mL}$, calibrated against an external standard. Sera were tested undiluted, with samples above the upper limit of quantification re-tested at 1:100 dilution. We also quantified the IgG sub-component of the plasma antibody response to RBD using bead-based ELISA on a Luminex 200 instrument. Here, recombinant His-tagged RBD (Wuhan or Delta/B.1.617.2 strain; R\&D Systems) was coupled to carboxylated xMAP beads (Bio-Rad). Plasma was tested in duplicate following 1:200 or 1:3200 
medRxiv preprint doi: https://doi.org/10.1101/2021.09.06.21263149; this version posted September 12, 2021. The copyright holder for this preprint (which was not certified by peer review) is the author/funder, who has granted medRxiv a license to display the preprint in perpetuity.

It is made available under a CC-BY-ND 4.0 International license .

dilution. Bound IgG was detected using PE-conjugated anti-human IgG secondary antibody (BioLegend) with results reported as arbitrary median fluorescence intensities (MFI).

ACE2 competition assay. We assessed the ability of plasma antibodies to block the interaction between RBD and the ACE2 receptor using competition ELISA on a Luminex 200 instrument. Here, plasma samples were diluted 1:100 in buffer containing a non-saturating concentration of soluble recombinant biotinylated ACE2 (50 nM; Abcam) prior to incubation with RBD-coupled xMAP beads. Bound ACE2 was detected using streptavidin-PE (Bio-Rad). ACE2 displacement was calculated as 100 - [MFI in the presence of plasma /MFI in the absence of plasma] and reported as a percentage.

Virus neutralization assays. Neutralizing activity in plasma was examined using a live SARSCoV-2 infectivity assay in a Containment Level 3 facility. Assays were performed using isolate USA-WA1/2020 (BEI Resources) and VeroE6-TMPRSS2 (JCRB-1819) target cells. Viral stock was adjusted to $50 \mathrm{TCID}_{50} / 200 \mu \mathrm{l}$ in DMEM in the presence of serial 2-fold dilutions of plasma (initial dilution, 1:20), incubated at $4^{\circ} \mathrm{C}$ for 1 hour and then added to target cells in 96 -well plates in triplicate. The appearance of viral cytopathic effect (CPE) was recorded 3 days post-infection. Neutralizing activity is reported as "present" if CPE was prevented in at least one of three replicate wells at a $1 / 20$ or higher plasma dilution (binary variable); or as the reciprocal plasma dilution necessary to prevent $\mathrm{CPE}$ in all triplicate wells (continuous variable).

Statistical analysis. Comparisons of binary variables between groups were performed using Fisher's exact test. Comparisons of continuous variables between groups were performed using 
medRxiv preprint doi: https://doi.org/10.1101/2021.09.06.21263149; this version posted September 12, 2021. The copyright holder for this preprint (which was not certified by peer review) is the author/funder, who has granted medRxiv a license to display the preprint in perpetuity.

It is made available under a CC-BY-ND 4.0 International license .

the Mann-Whitney U-test (for unpaired data) or Wilcoxon test (for paired data). Ordinary least squares regression was used to examine relationships between continuous variables. Multiple linear regression was employed to investigate the relationship between age (per year increment), sex (female as reference group), Ethnicity (non-white as reference group), number of chronic health conditions (per number increment), vaccine type (Pfizer as reference group) and sampling date following vaccine dose (per day increment) on immunogenicity outcomes. All tests were two-tailed, with $\mathrm{p}=0.05$ considered statistically significant. Analyses were conducted using Prism v9.2.0 (GraphPad).

\section{RESULTS}

\section{Lower RBD binding antibodies associated with older age and number of chronic health conditions.}

Characteristics of the 151 participants, which included 89 healthcare workers (HCW) and 62 older adults (Seniors+LTC) are shown in Table 1. All participants received two doses of an mRNA vaccine between December 2020-July 2021. Due to limited initial vaccine supply in Canada, the interval between first and second doses was extended to a maximum of 112 days in British Columbia beginning on March 1, 2021, so participants received their second dose a median of 91 days after the first (interquartile range [IQR] 70-99 days). Samples were collected before vaccination to assess prior exposure to SARS-CoV-2 ( $\mathrm{n}=142)$; at one month following the first $(\mathrm{n}=141)$ and second $(\mathrm{n}=147)$ doses to quantify response magnitude; and at three months following the second dose $(\mathrm{n}=30)$ to examine response durability.

HCW and older adults (Seniors+LTC) were a median of 41 and 79 years old respectively, and predominantly female. At study entry, 14 participants (9.3\%; eight HCW and six older 
adults) were identified as COVID-19 convalescent based on the presence of anti-SARS-CoV-2 N antibodies. Nine participants $(6 \%$; one $\mathrm{HCW}$ and eight older adults) received the Moderna vaccine for their first dose, while 142 (94\%) received Pfizer. In addition to age, the two groups differed significantly in terms of ethnicity $(p=0.0002)$, number of chronic health conditions $(\mathrm{p}<0.0001)$, vaccine received $(\mathrm{p}=0.0015)$, time between doses $(\mathrm{p}<0.0001)$ and specimen collection date after the first dose $(\mathrm{p}=0.0069)$.

We quantified interim and peak anti-RBD IgG binding antibodies in plasma one month after the first and second vaccine doses using a bead-based Luminex ELISA assay. After one dose, median anti-RBD IgG titers were 4.2-fold lower in Seniors+LTC compared to HCW $(\mathrm{p}<0.0001)$ (Figure 1A). In contrast, the 14 COVID-19 convalescent participants mounted 190- and 840-fold higher IgG responses after one dose compared to COVID-19 naïve HCW and Seniors $+\mathrm{LTC}$, respectively (both $\mathrm{p}<0.0001$ ), consistent with prior studies demonstrating robust reactivity to one dose in previously infected individuals ${ }^{18}$. After two doses, median antiRBD IgG responses increased by a median of $>2 \log$ in both naïve groups (Figure 1C;

Supplemental Figure 1A), with some indication that the extent of boosting was marginally higher in older individuals (Supplemental Figure 1B), but no further increase was observed in convalescent participants. Indeed, after two doses the median IgG values in $\mathrm{HCW}$ reached equivalence with the convalescent group, while values in Seniors + LTC remained $\sim 3$-fold lower (both comparisons $\mathrm{p}<0.0001$ ), with two doubly-vaccinated older adults continuing to exhibit very poor responses (Figure 1C). No difference in binding antibody responses was seen between Seniors and LTC residents after one or two vaccine doses when these groups were analyzed separately (both $\mathrm{p}>0.3$; not shown), supporting their analysis as a single group of older adults. 
Among COVID-19 naïve individuals, we estimate using univariable linear regression that every 10 years of older age was associated, on average, with 0.17 and $0.12 \log _{10} \operatorname{lower}_{\operatorname{IgG}}$ responses, after one and two vaccine doses, respectively (Figures 1B,D). Multivariable analyses in COVID-19 naïve individuals adjusting for sex (as studies have reported enhanced immune function in females following pathogen infection and vaccination ${ }^{19}$ ), ethnicity, number of chronic health conditions, vaccine brand, and day of specimen collection following immunization confirmed that age remained significantly associated with $\mathrm{IgG}$ responses after one and two vaccine doses $(\mathrm{p}=0.0001$ and $\mathrm{p}=0.0005$, respectively), and that the number of chronic health conditions also contributed negatively to these outcomes $(p=0.005$ and $p=0.05$, respectively) (Table 2). Note that the multivariable model for the response after two vaccine doses did not include the dosing interval as this variable was collinear with our age-defined participant groupings (the median dosing interval was lower in Senior+LTC compared to HCW because most LTC residents received two doses before BC extended the dose interval to 112 days). The lack of relationship between dosing interval and IgG response within $\mathrm{HCW}$ and Seniors+LTC groups (whose dose intervals ranged from 30-122 and 42-102 days, respectively, both $\mathrm{p}>0.6$, not shown) provided additional support for excluding this variable from the model. Highly comparable results were obtained from sera using the commercial Roche Elecsys Anti-SARS-CoV-2 S assay, which assesses total anti-RBD antibodies (Supplemental Figure 2 and Supplemental Table 1), confirming that the binding antibody response elicited by COVID19 mRNA vaccines is significantly lower in older adults, even after two immunizations. 
medRxiv preprint doi: https://doi.org/10.1101/2021.09.06.21263149; this version posted September 12, 2021. The copyright holder for this preprint (which was not certified by peer review) is the author/funder, who has granted medRxiv a license to display the preprint in perpetuity.

It is made available under a CC-BY-ND 4.0 International license .

\section{Lower ability to block ACE2 receptor binding is associated with older age and male sex.}

We next assessed the ability of plasma to block the RBD-ACE2 interaction using Luminex ELISA, a higher throughput approach to estimate potential viral neutralization activity. After one vaccine dose, $\mathrm{HCW}$ and Seniors+LTC exhibited median $45 \%$ and $38 \%$ ACE2 displacement activities, respectively, indicating lower function among older adults $(\mathrm{p}=0.0026)$

(Figure 2A). In contrast, convalescent participants exhibited a median 92\% ACE2 displacement activity after one dose ( $\mathrm{p}<0.0001$ compared to both naive groups). Following two vaccine doses, HCW exhibited a median 91\% ACE2 displacement activity compared to a median of $70 \%$ in Seniors + LTC $(\mathrm{p}<0.0001)$ (Figure 2C). Of note, while the second dose boosted binding antibodies to similar (or higher) levels in Seniors+LTC compared to HCW (Supplemental Figure 1A, B), it had significantly less of an impact on the ability of these antibodies to displace ACE2 in Seniors+LTC compared to HCW ( $p=0.0003)$ (Supplemental Figure 1C). This suggests that, though these mRNA vaccines clearly stimulate antibody production, antibody functions such as affinity maturation may be diminished with age.

Among COVID-19 naïve individuals, we estimate using univariable linear regression that every 10 years of older age was associated, on average, with $2.0 \%$ and $4.4 \%$ lower ACE2 displacement activity after one and two vaccine doses respectively (Figures 2B,D).

Multivariable regression in COVID-19 naïve individuals confirmed that age remained associated with ACE2 displacement activity after one $(\mathrm{p}=0.04)$ and two $(\mathrm{p}<0.0001)$ doses $($ Table 2$)$.

Female sex was independently associated with $6.5 \%$ higher ACE2 displacement activity after one dose $(\mathrm{p}=0.01)$, which is notable since women have been reported to display higher neutralizing antibody responses following infection and vaccination ${ }^{19}$. Chronic health conditions also played a potential negative role on ACE2 displacement activity after two doses $(p=0.07)$. 
medRxiv preprint doi: https://doi.org/10.1101/2021.09.06.21263149; this version posted September 12, 2021. The copyright holder for this preprint (which was not certified by peer review) is the author/funder, who has granted medRxiv a license to display the preprint in perpetuity.

It is made available under a CC-BY-ND 4.0 International license .

\section{Weaker virus neutralizing activity is associated with age and chronic health conditions}

We next performed SARS-CoV-2 neutralization assays to quantify the ability of plasma to block virus infection of target cells, which may involve spike epitopes outside of the RBD. Following one vaccine dose, 15 of 72 (21\%) COVID-19 naïve HCW displayed modest evidence of neutralizing activity (at 1:20 dilution), compared to only one of 32 (3\%) Seniors+LTC $(\mathrm{p}=0.02)$ (Figure 3A), a relationship that also held when age was analyzed as a continuous variable (Figure 3B). In contrast, all 13 convalescent participants efficiently neutralized live SARS-CoV-2 following one vaccine dose (median reciprocal titer of 240) (Figure 3A), despite showing no neutralization activity at 1:20 plasma dilution prior to vaccination (not shown). Following the second vaccine dose, all 15 tested HCW displayed neutralizing activity at 1:20 dilution compared to only 11 of $17(65 \%)$ older adults ( $p=0.009$; Figure 3C). Consistent with ACE2 displacement results, the second vaccine dose boosted virus neutralization titers significantly better in HCW compared to Seniors+LTC (Supplemental Figure 1E,F). Indeed, ACE2 displacement activity correlated with virus neutralization activity (Spearman $\rho=0.82$; $\mathrm{p}<0.0001$ ), suggesting that the former is a reasonable surrogate for the latter. In univariate analyses of COVID-19 naïve individuals, we estimate that every 10 years of older age was associated with an average $0.4 \log 2$ lower neutralization after two doses (Figure 3D). In multivariable analyses in COVID-19 naïve individuals, age remained the only significant contributor to virus neutralization activity after one and two vaccine doses $(p=0.01$ and $p=0.006$, respectively) (Table 2). 
medRxiv preprint doi: https://doi.org/10.1101/2021.09.06.21263149; this version posted September 12, 2021. The copyright holder for this preprint (which was not certified by peer review) is the author/funder, who has granted medRxiv a license to display the preprint in perpetuity.

It is made available under a CC-BY-ND 4.0 International license .

\section{Vaccine-induced antibody responses decline over time across all ages}

At time of writing, plasma from 30 COVID-19 naive participants (13 HCW and 17 LTC residents, median 38 and 82 years old respectively) were available at three months following two vaccine doses, allowing us to assess vaccine response durability. In essentially all participants, antibody responses declined markedly between one and three months following the second dose: median IgG binding antibodies declined 7-fold and 4.5-fold in HCW and LTC, respectively (both $\mathrm{p} \leq 0.0001$; Figure 4A) while median ACE2 displacement activity declined by $39 \%$ in HCW $(\mathrm{p}=0.0002)$ and by $30 \%$ in LTC $(\mathrm{p}=0.003)$ (Figure 4B). Median virus neutralization activity declined 4-fold in HCW ( $\mathrm{p}=0.0005)$ and 2 -fold in $\mathrm{LTC}$, though the latter did not reach statistical significance $(\mathrm{p}=0.06)$ (Figure 4C). Despite these near-universal temporal reductions, group-specific medians remained substantially higher in HCW compared to LTC participants in all assays, with median residual activities in $\mathrm{HCW}$ at three months after the second dose approximating the peak response in LTC one month after this dose.

\section{Impaired ability to block ACE2 binding by Delta variant among older adults.}

Given recent concerns that certain SARS-CoV-2 variants may be more transmissible or evade aspects of host immunity ${ }^{20,21}$, we examined binding antibodies and ACE2 competition activity against the widespread B.1.617.2 (Delta) variant at one and three months following the second vaccine dose in the same subset. Overall, anti-RBD binding antibody levels were equivalent between the original Wuhan strain and the Delta variant within each group and timepoint tested (all $\mathrm{p}>0.3$; Figure 5A). Nevertheless, responses in LTC participants were lower than those in $\mathrm{HCW}$ at all timepoints, and responses in both groups waned considerably between one and three months after the second dose (Figure 5A). In contrast, plasma from both groups 
medRxiv preprint doi: https://doi.org/10.1101/2021.09.06.21263149; this version posted September 12, 2021. The copyright holder for this

It is made available under a CC-BY-ND 4.0 International license .

was impaired in its ability to block ACE2 receptor engagement by the Delta RBD compared to the Wuhan RBD: in HCW, median ACE2 displacement values were 7\% lower against Delta at both one and three months after vaccination (both $\mathrm{p} \leq 0.0002$ ), while in LTC, median ACE2 displacement values were $\sim 15 \%$ lower against Delta at both time points (both $\mathrm{p} \leq 0.0001$ )

(Figure 5B). These results indicate that, while two vaccine doses can elicit binding antibodies that cross-recognize Delta RBD, these responses may be less able to prevent infection by this variant. This observation is consistent with a recent report showing reduced ability of plasma from convalescent and vaccinated individuals to neutralize this strain ${ }^{22}$. Considering the lower peak immune response in older adults, combined with the waning of these responses over time, our data suggest that older adults will remain more susceptible to infection by the Delta variant even after two vaccine doses.

\section{DISCUSSION}

This study extends our understanding of the magnitude and durability of antibody responses induced by COVID-19 mRNA vaccines across the adult age spectrum ${ }^{23-27}$. Overall, responses in older adults are impaired both quantitatively (i.e., fewer binding antibodies) and functionally (i.e., lower ACE2 displacement and neutralization activity) compared to younger adults, even after two vaccine doses. Importantly, multivariable analyses confirmed older age as an independent determinant of poorer immune responses following one or both vaccine doses, even after controlling for chronic health conditions that can accumulate with age and

compromise immunity ${ }^{15-17}$. Moreover, though the number of chronic health conditions was also independently associated with lower binding antibody titers and male sex was independently associated with lower ACE2 displacement activity after one dose, the negative impact of these 
medRxiv preprint doi: https://doi.org/10.1101/2021.09.06.21263149; this version posted September 12, 2021. The copyright holder for this

It is made available under a CC-BY-ND 4.0 International license .

variables on vaccine responses diminished after two doses. Our results thus identify age as the most critical variable modulating antibody responses after COVID-19 mRNA vaccination.

We also explored the durability of the humoral response at three months following the second vaccine dose in a subset of HCW (median age 38 years) and LTC residents (median age 82 years). Despite this timepoint being only two months after we measured peak immune responses, antibodies had waned significantly in both groups: indeed, assuming that decay occurred exponentially, we estimate the half-life of anti-RBD binding antibodies to be 37 days [95\% CI 32-42] in our study participants. This suggests that antibody durability following mRNA vaccination is substantially lower compared to that following infection, which was estimated to be $\sim 116$ days in a recent study of convalescent individuals ${ }^{28}$. Regardless, humoral responses remained overall substantially lower among LTC residents at all timepoints tested, and the "diminished" binding antibody levels observed in HCW at three months following the second vaccine dose were comparable to "peak" levels seen in LTC at one month following the second dose, allowing us to contextualize the extent of immune disadvantage in older adults. Of note, while antibody recognition of the B.1.617.2 (Delta) variant RBD was similar to that of the Wuhan strain, ACE2 competition activity against the Delta RBD was universally reduced, suggesting that older adults will remain more susceptible to infection by this variant at all stages after vaccination due to their weaker overall responses compared to younger individuals.

Our observations are consistent with evidence from other infections describing poorer immune reactivity among older adults that can be mitigated in part by modifying vaccine formulations (e.g., by increasing antigen concentrations or additional adjuvants) or providing booster immunizations more frequently ${ }^{15-17}$. Recent reports from the UK ${ }^{29}$ and Germany ${ }^{30}$ have also demonstrated age-related impairments in binding and neutralizing antibodies following 
medRxiv preprint doi: https://doi.org/10.1101/2021.09.06.21263149; this version posted September 12, 2021. The copyright holder for this preprint (which was not certified by peer review) is the author/funder, who has granted medRxiv a license to display the preprint in perpetuity.

It is made available under a CC-BY-ND 4.0 International license .

immunization with the COVID-19 mRNA vaccine BNT162b2, though T cell responses were more similar between younger and older participants. However, these studies did not examine the durability of vaccine-induced immune responses in older adults, which is of paramount importance as more people complete the current two-dose vaccine schedule. Indeed, recent increases in SARS-CoV-2 infections among doubly vaccinated individuals ${ }^{31}$, including outbreaks in LTC facilities ${ }^{14}$, underscores this ongoing risk.

Our observation that $35 \%$ of older adults failed to neutralize SARS-CoV-2 (USAWA1/2020 strain) even after two vaccine doses also emphasizes the ongoing infection risk in this population. Furthermore, while we did not perform virus neutralization assays using the Delta variant, our ACE2 competition results suggest that neutralization activity against Delta will be even lower than that against the Wuhan strain. Given the ability of SARS-CoV-2 variants to evade at least some aspects of vaccine-elicited immunity ${ }^{20}$, our results support the prioritization of older adults for receipt of supplemental vaccine doses.

A limitation of our study is that precise immune correlates of protection for SARSCoV-2 transmission and disease severity remain incompletely characterized ${ }^{32}$, so the implications of our results as they relate to individual-level control of COVID-19 remain uncertain. The levels of immunity induced in older adults seen here following vaccination may be sufficient to prevent symptomatic infection or severe disease in many cases, so studies linking vaccine immunogenicity data to clinical outcomes specifically among older adults are needed. Due to the timing of the vaccine rollout in British Columbia, our sample size for the durability assessments was modest; however, the weaker responses observed among LTC residents were nevertheless statistically significant. Due to small numbers of participants who received Moderna, we were unable to assess differences in responses between mRNA vaccines ${ }^{14,33}$. 
medRxiv preprint doi: https://doi.org/10.1101/2021.09.06.21263149; this version posted September 12, 2021. The copyright holder for this preprint (which was not certified by peer review) is the author/funder, who has granted medRxiv a license to display the preprint in perpetuity.

It is made available under a CC-BY-ND 4.0 International license .

Overall, our results extend a growing body of evidence indicating that COVID-19

mRNA vaccines are less immunogenic in older compared to younger adults and reveal substantial waning of immunity across all ages in the first three months following receipt of two doses of vaccine. The combined effects of lower peak immunity and natural waning of vaccineinduced responses may leave older adults at continued risk of infection by SARS-CoV-2 or its variants. 


\section{FUNDING STATEMENT}

This work was supported by the Public Health Agency of Canada through a COVID-19 Immunology Task Force COVID-19 "Hot Spots" Award (2021-HQ-000120 to MAB, ZLB, MGR) and the Canada Foundation for Innovation through Exceptional Opportunities Fund COVID-19 awards (to MAB, MN, MD, RP, ZLB) and the National Institute of Allergy and Infectious Diseases of the National Institutes of Health (R01AI134229 to RP). GU and FHO are supported by Ph.D. fellowships from the Sub-Saharan African Network for TB/HIV Research Excellence (SANTHE), a DELTAS Africa Initiative [grant \# DEL-15-006]. The DELTAS Africa Initiative is an independent funding scheme of the African Academy of Sciences (AAS)'s Alliance for Accelerating Excellence in Science in Africa (AESA) and supported by the New Partnership for Africa's Development Planning and Coordinating Agency (NEPAD Agency) with funding from the Wellcome Trust [grant \# 107752/Z/15/Z] and the UK government. The views expressed in this publication are those of the authors and not necessarily those of AAS, NEPAD Agency, Wellcome Trust or the UK government. LYL was supported by an SFU Undergraduate Research Award. ZLB holds a Scholar Award from the Michael Smith Foundation for Health Research.

\section{ACKNOWLEDGEMENTS}

We thank the leadership and staff of Providence Health Care, including long-term care and assisted living residences, for their support of this study. We thank the phlebotomists and laboratory staff at St. Paul's Hospital, the BC Centre for Excellence in HIV/AIDS and Simon Fraser University for assistance. Above all, we thank the participants, without whom this study would not have been possible. 


\section{REFERENCES}

1. Fisman DN, Bogoch I, Lapointe-Shaw L, McCready J, Tuite AR. Risk Factors Associated With Mortality Among Residents With Coronavirus Disease 2019 (COVID-19) in Longterm Care Facilities in Ontario, Canada. JAMA Netw Open 2020; 3(7): e2015957.

2. Chinnadurai R, Ogedengbe $\mathrm{O}$, Agarwal $\mathrm{P}$, et al. Older age and frailty are the chief predictors of mortality in COVID-19 patients admitted to an acute medical unit in a secondary care setting- a cohort study. BMC Geriatr 2020; 20(1): 409.

3. Banerjee A, Pasea L, Harris S, et al. Estimating excess 1-year mortality associated with the COVID-19 pandemic according to underlying conditions and age: a population-based cohort study. Lancet 2020; 395(10238): 1715-25.

4. Sharma O, Sultan AA, Ding H, Triggle CR. A Review of the Progress and Challenges of Developing a Vaccine for COVID-19. Front Immunol 2020; 11: 585354.

5. Poland GA, Ovsyannikova IG, Kennedy RB. SARS-CoV-2 immunity: review and applications to phase 3 vaccine candidates. Lancet 2020; 396(10262): 1595-606.

6. Baden LR, El Sahly HM, Essink B, et al. Efficacy and Safety of the mRNA-1273 SARSCoV-2 Vaccine. N Engl J Med 2021; 384(5): 403-16.

7. Polack FP, Thomas SJ, Kitchin N, et al. Safety and Efficacy of the BNT162b2 mRNA Covid-19 Vaccine. N Engl J Med 2020; 383(27): 2603-15.

8. Hodgson SH, Mansatta K, Mallett G, Harris V, Emary KRW, Pollard AJ. What defines an efficacious COVID-19 vaccine? A review of the challenges assessing the clinical efficacy of vaccines against SARS-CoV-2. Lancet Infect Dis 2021; 21(2): e26-e35.

9. Abu Jabal K, Ben-Amram H, Beiruti K, et al. Impact of age, ethnicity, sex and prior infection status on immunogenicity following a single dose of the BNT162b2 mRNA 
medRxiv preprint doi: https://doi.org/10.1101/2021.09.06.21263149; this version posted September 12, 2021. The copyright holder for this preprint (which was not certified by peer review) is the author/funder, who has granted medRxiv a license to display the preprint in perpetuity.

It is made available under a CC-BY-ND 4.0 International license .

COVID-19 vaccine: real-world evidence from healthcare workers, Israel, December 2020 to January 2021. Euro Surveill 2021; 26(6).

10. Dagan N, Barda N, Kepten E, et al. BNT162b2 mRNA Covid-19 Vaccine in a Nationwide Mass Vaccination Setting. N Engl J Med 2021.

11. Grupper A, Rabinowich L, Schwartz D, et al. Reduced humoral response to mRNA SARSCoV-2 BNT162b2 vaccine in kidney transplant recipients without prior exposure to the virus. Am J Transplant 2021; 21(8): 2719-26.

12. Massarweh A, Eliakim-Raz N, Stemmer A, et al. Evaluation of Seropositivity Following BNT162b2 Messenger RNA Vaccination for SARS-CoV-2 in Patients Undergoing Treatment for Cancer. JAMA Oncol 2021; 7(8): 1133-40.

13. Monin L, Laing AG, Munoz-Ruiz M, et al. Safety and immunogenicity of one versus two doses of the COVID-19 vaccine BNT162b2 for patients with cancer: interim analysis of a prospective observational study. Lancet Oncol 2021; 22(6): 765-78.

14. Nanduri S, Pilishvili T, Derado G, et al. Effectiveness of Pfizer-BioNTech and Moderna Vaccines in Preventing SARS-CoV-2 Infection Among Nursing Home Residents Before and During Widespread Circulation of the SARS-CoV-2 B.1.617.2 (Delta) Variant - National Healthcare Safety Network, March 1-August 1, 2021. MMWR Morb Mortal Wkly Rep 2021; 70(34): 1163-6.

15. Pereira $\mathrm{B}, \mathrm{Xu} \mathrm{XN}, \mathrm{Akbar} \mathrm{AN}$. Targeting Inflammation and Immunosenescence to Improve Vaccine Responses in the Elderly. Front Immunol 2020; 11: 583019.

16. Zimmermann P, Curtis N. Factors That Influence the Immune Response to Vaccination. Clin Microbiol Rev 2019; 32(2). 
medRxiv preprint doi: https://doi.org/10.1101/2021.09.06.21263149; this version posted September 12, 2021. The copyright holder for this preprint (which was not certified by peer review) is the author/funder, who has granted medRxiv a license to display the preprint in perpetuity.

It is made available under a CC-BY-ND 4.0 International license .

17. Merani S, Pawelec G, Kuchel GA, McElhaney JE. Impact of Aging and Cytomegalovirus on Immunological Response to Influenza Vaccination and Infection. Front Immunol 2017; 8: 784.

18. Goel RR, Apostolidis SA, Painter MM, et al. Distinct antibody and memory B cell responses in SARS-CoV-2 naive and recovered individuals following mRNA vaccination. Sci Immunol 2021; 6(58).

19. Cook IF. Sexual dimorphism of humoral immunity with human vaccines. Vaccine 2008; 26(29-30): 3551-5.

20. Gupta RK. Will SARS-CoV-2 variants of concern affect the promise of vaccines? Nat Rev Immunol 2021; 21(6): 340-1.

21. Plante JA, Mitchell BM, Plante KS, Debbink K, Weaver SC, Menachery VD. The variant gambit: COVID-19's next move. Cell Host Microbe 2021; 29(4): 508-15.

22. Planas D, Veyer D, Baidaliuk A, et al. Reduced sensitivity of SARS-CoV-2 variant Delta to antibody neutralization. Nature 2021; 596(7871): 276-80.

23. Widge AT, Rouphael NG, Jackson LA, et al. Durability of Responses after SARS-CoV-2 mRNA-1273 Vaccination. N Engl J Med 2021; 384(1): 80-2.

24. Thomas SJ, Moreira ED, Kitchin N, et al. Six Month Safety and Efficacy of the BNT162b2 mRNA COVID-19 Vaccine. medRxiv 2021: 2021.07.28.21261159.

25. Haas EJ, Angulo FJ, McLaughlin JM, et al. Impact and effectiveness of mRNA BNT162b2 vaccine against SARS-CoV-2 infections and COVID-19 cases, hospitalisations, and deaths following a nationwide vaccination campaign in Israel: an observational study using national surveillance data. Lancet 2021; 397(10287): 1819-29. 
26. Salvagno GL, Henry BM, di Piazza G, et al. Anti-SARS-CoV-2 Receptor-Binding Domain Total Antibodies Response in Seropositive and Seronegative Healthcare Workers Undergoing COVID-19 mRNA BNT162b2 Vaccination. Diagnostics (Basel) 2021; 11(5).

27. Tenforde MW, Olson SM, Self WH, et al. Effectiveness of Pfizer-BioNTech and Moderna Vaccines Against COVID-19 Among Hospitalized Adults Aged >/=65 Years - United States, January-March 2021. MMWR Morb Mortal Wkly Rep 2021; 70(18): 674-9.

28. Cohen KW, Linderman SL, Moodie Z, et al. Longitudinal analysis shows durable and broad immune memory after SARS-CoV-2 infection with persisting antibody responses and memory B and T cells. Cell Rep Med 2021; 2(7): 100354.

29. Collier DA, Ferreira I, Kotagiri P, et al. Age-related immune response heterogeneity to SARS-CoV-2 vaccine BNT162b2. Nature 2021; 596(7872): 417-22.

30. Muller L, Andree M, Moskorz W, et al. Age-dependent immune response to the Biontech/Pfizer BNT162b2 COVID-19 vaccination. Clin Infect Dis 2021.

31. Keehner J, Horton LE, Binkin NJ, et al. Resurgence of SARS-CoV-2 Infection in a Highly Vaccinated Health System Workforce. New England Journal of Medicine 2021.

32. Feng S, Phillips DJ, White T, et al. Correlates of protection against symptomatic and asymptomatic SARS-CoV-2 infection. medRxiv 2021: 2021.06.21.21258528.

33. Abe KT, Hu Q, Mozafarihashjin M, et al. Neutralizing antibody responses to SARS-CoV-2 variants in vaccinated Ontario long-term care home residents and workers. medRxiv 2021: 2021.08.06.21261721. 
medRxiv preprint doi: https://doi.org/10.1101/2021.09.06.21263149; this version posted September 12, 2021. The copyright holder for this preprint (which was not certified by peer review) is the author/funder, who has granted medRxiv a license to display the preprint in perpetuity.

It is made available under a CC-BY-ND 4.0 International license .

Table 1. Study Participants $(\mathrm{n}=151)$

\begin{tabular}{|c|c|c|c|}
\hline & Health Care Workers $(n=89)$ & Seniors + LTC $(n=62)$ & p-value \\
\hline Age in years, median [IQR] & $41[35-50]$ & $79[73-86]$ & $<0.0001$ \\
\hline Female Sex, n (\%) & $65(73 \%)$ & $43(69 \%)$ & 0.71 \\
\hline White/Caucasian Ethnicity, n (\%) & $40(45 \%)$ & $47(76 \%)$ & 0.0002 \\
\hline COVID-19 convalescent (anti-N Ab+), n (\%) & $8(9 \%)$ & $6(10 \%)$ & $>0.99$ \\
\hline $\begin{array}{l}\text { Chronic health or immunosuppresive } \\
\text { conditions, median [IQR] }\end{array}$ & $0[0-0]$ & $1[0-2]$ & $<0.0001$ \\
\hline Pfizer mRNA Vaccine, n (\%) & $88(99 \%)$ & $54(87 \%)$ & 0.0015 \\
\hline Time between doses in days, median [IQR] & $97[91-103]$ & $78[45-86]$ & $<0.0001$ \\
\hline $\begin{array}{l}\text { Specimens collected one month after first } \\
\text { dose, n (\%) }\end{array}$ & $87(98 \%)$ & $54(87 \%)$ & n.a. \\
\hline $\begin{array}{l}\text { Day of specimen collection one month after } \\
\text { first dose, median [IQR] }\end{array}$ & $29[27-31]$ & $30[28-32]$ & 0.0069 \\
\hline $\begin{array}{l}\text { Specimens collected one month after second } \\
\text { dose, } \mathbf{n}(\%)\end{array}$ & $89(100 \%)$ & $58(87 \%)$ & n.a. \\
\hline $\begin{array}{l}\text { Day of specimen collection one month after } \\
\text { second dose, median [IQR] }\end{array}$ & $30[29-32]$ & $30[29-32]$ & 0.96 \\
\hline $\begin{array}{l}\text { Specimens collected three months after } \\
\text { second dose, n (\%) }\end{array}$ & $13(15 \%)$ & $17(27 \%)$ & n.a. \\
\hline $\begin{array}{l}\text { Day of specimen collection three months after } \\
\text { second dose, median [IQR] }\end{array}$ & 91 [90-95] & 90 [90-91] & 0.19 \\
\hline
\end{tabular}

IQR, interquartile range; n.a., not applicable 


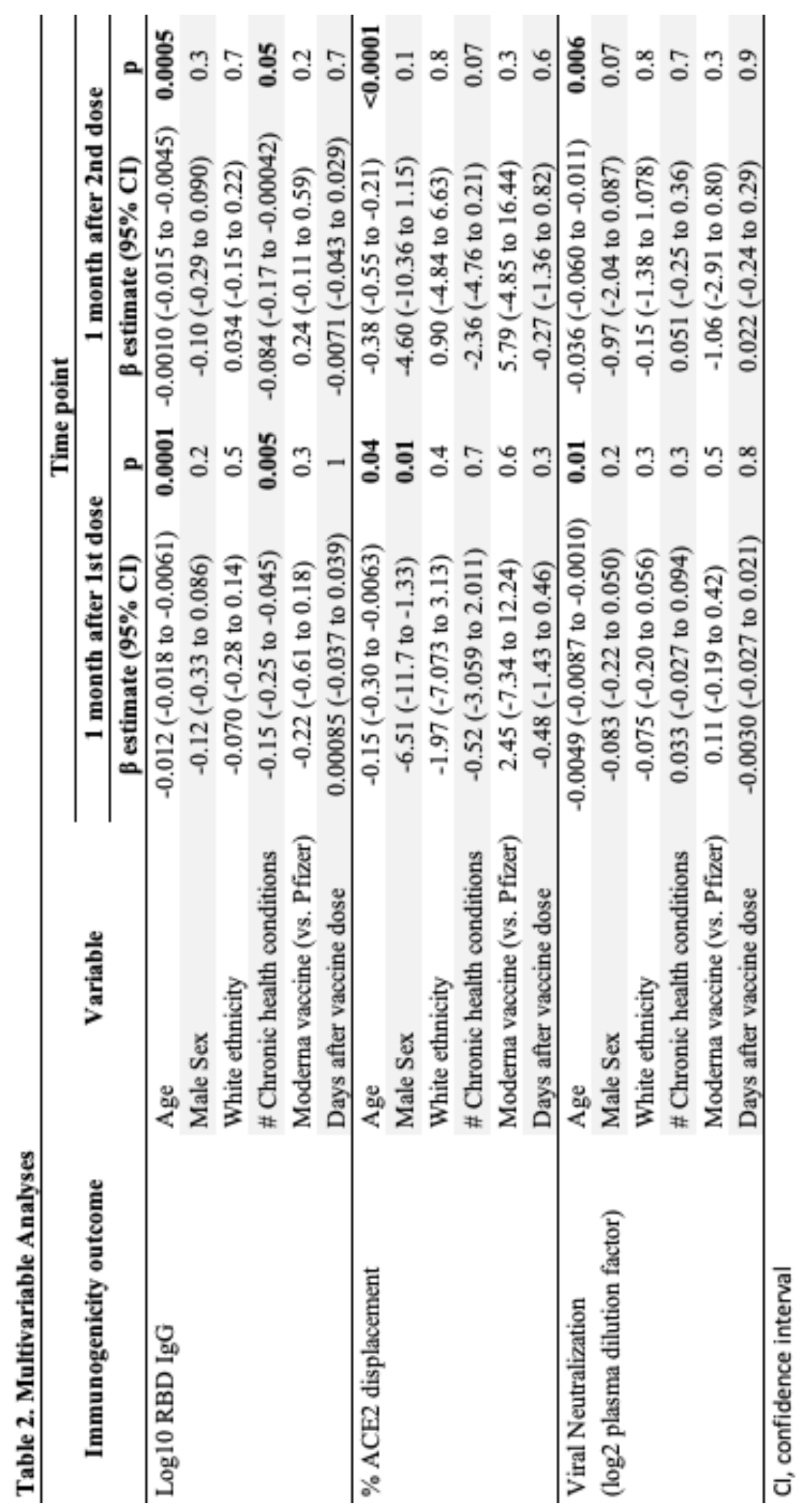



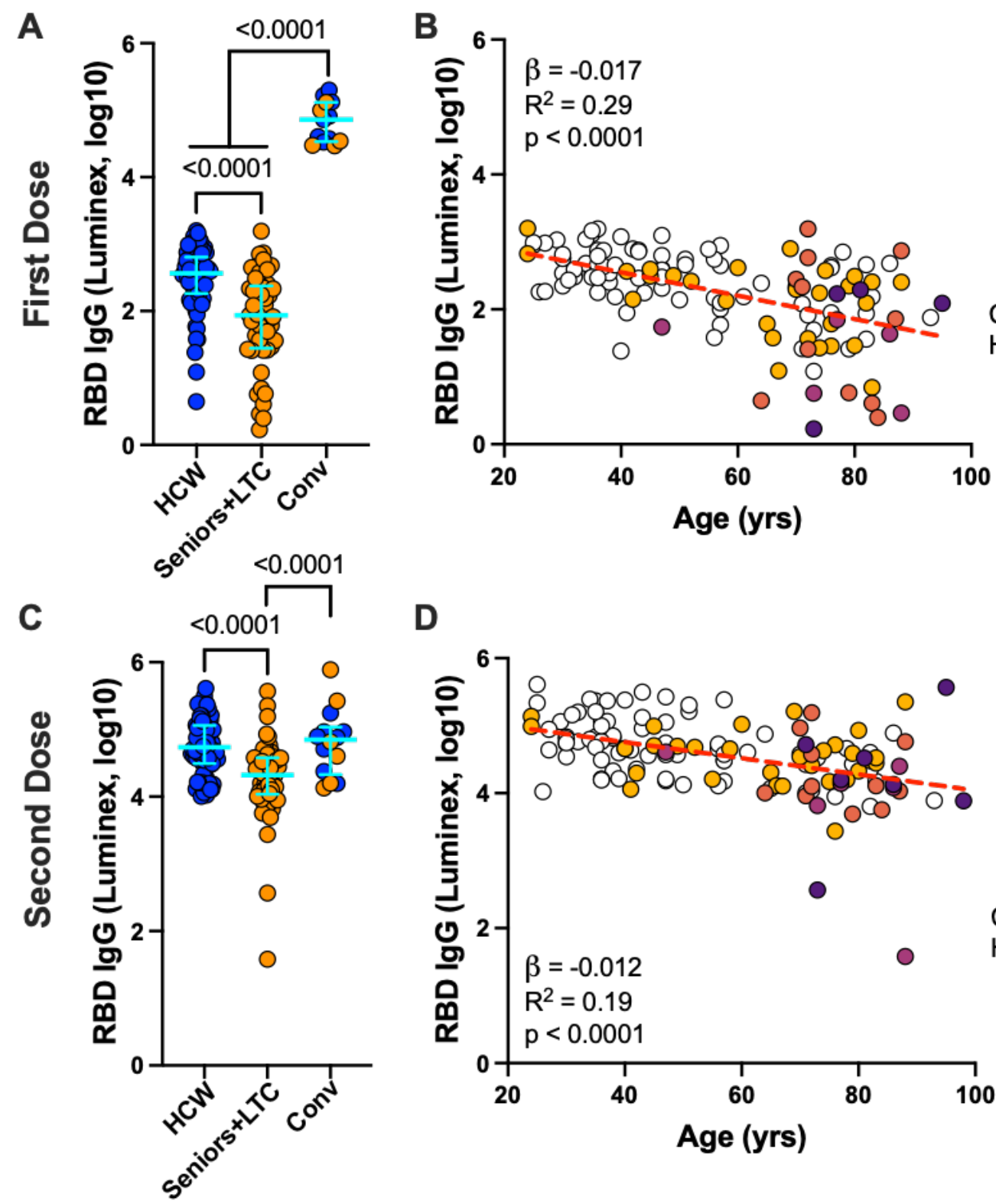

Covariable: Chronic Health Conditions

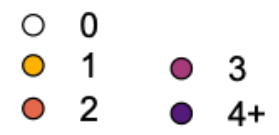

D

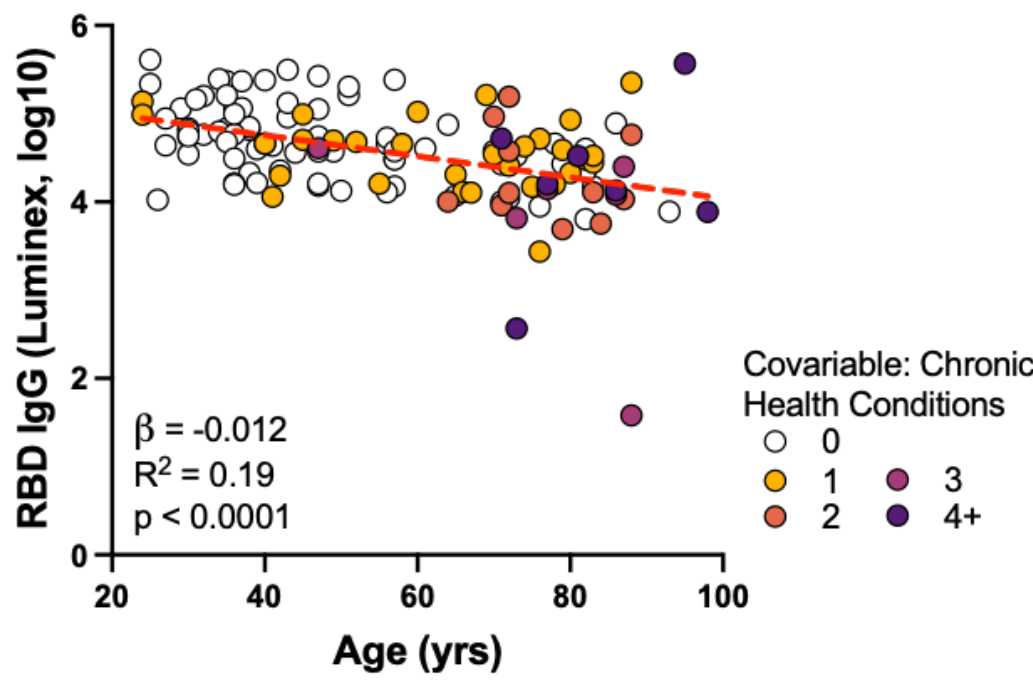

Figure 1: Binding antibody responses to spike RBD following one and two doses of a COVID-19 mRNA vaccine are lower in older adults. 


\section{Figure 1: Binding antibody responses to spike RBD following one and two doses of a}

COVID-19 mRNA vaccine are lower in older adults. Panel $A$ : Binding IgG responses to the SARS-CoV-2 spike RBD in plasma, measured using a Luminex ELISA assay, following one dose of a COVID-19 mRNA vaccine in Seniors+LTC (comprising individuals living in longterm care or assisted living facilities and seniors living independently; orange circles) and healthcare workers (HCW; blue circles), who were COVID-19 naive at study entry. The third group, convalescents ("Conv") denotes participants with anti-N antibodies at study entry, colored as above. Bars represent median and IQR. P-values were computed using the Mann-Whitney Utest. Panel B: Same data as the HCW and Seniors+LTC groups shown in panel A, but plotted by age, and where participants are colored based on their number of chronic health conditions, which remained significant in multivariable analyses (see Table 2). Statistics computed using ordinary least-squares regression, also shown as dotted line. Panels $C, D$ : Same as A and B, but for responses following two doses of mRNA vaccine. 


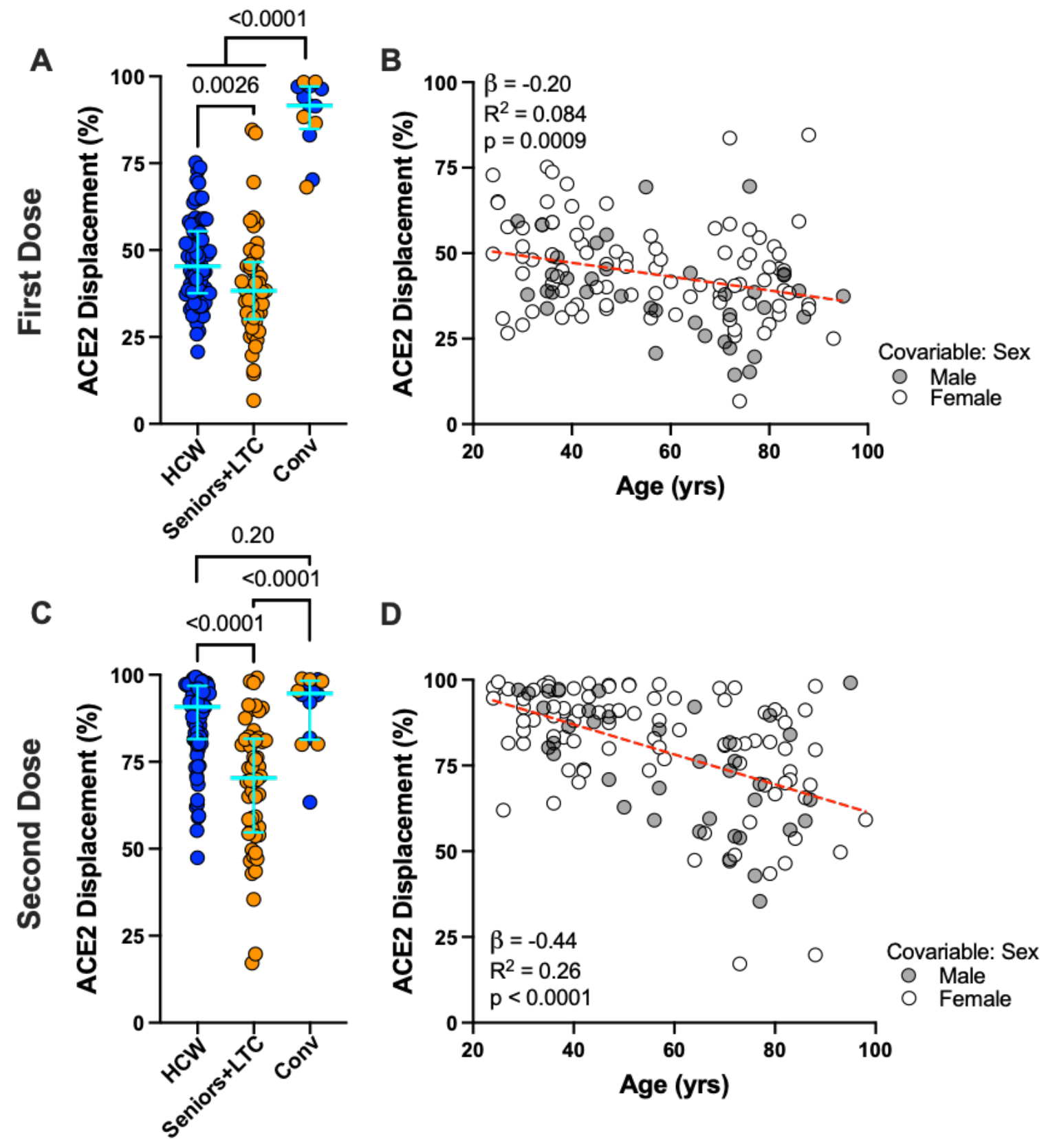

Figure 2: Ability of vaccine-induced antibodies to block ACE2-receptor binding is weaker in older adults. 
Figure 2: Ability of vaccine-induced antibodies to block ACE2-receptor binding is weaker in older adults. Panel A: Ability of vaccine-induced plasma antibodies to displace soluble ACE2-receptor from spike RBD, measured using a Luminex ELISA assay, following one dose of vaccine in COVID-19 naive Seniors+LTC (orange circles), HCW (blue circles), and COVID19 convalescent participants ("Conv"; colored as above). Bars represent median and IQR. Pvalues computed using the Mann-Whitney U-test. Panel B: Same data as the HCW and Seniors+LTC groups shown in panel A, but plotted by age, and colored by sex, which remained significant in multivariable analyses (see Table 2). Statistics computed using ordinary leastsquares regression, also shown as dotted line. Panels $C$, D: Same as A and B, but for responses following two doses of mRNA vaccine. 

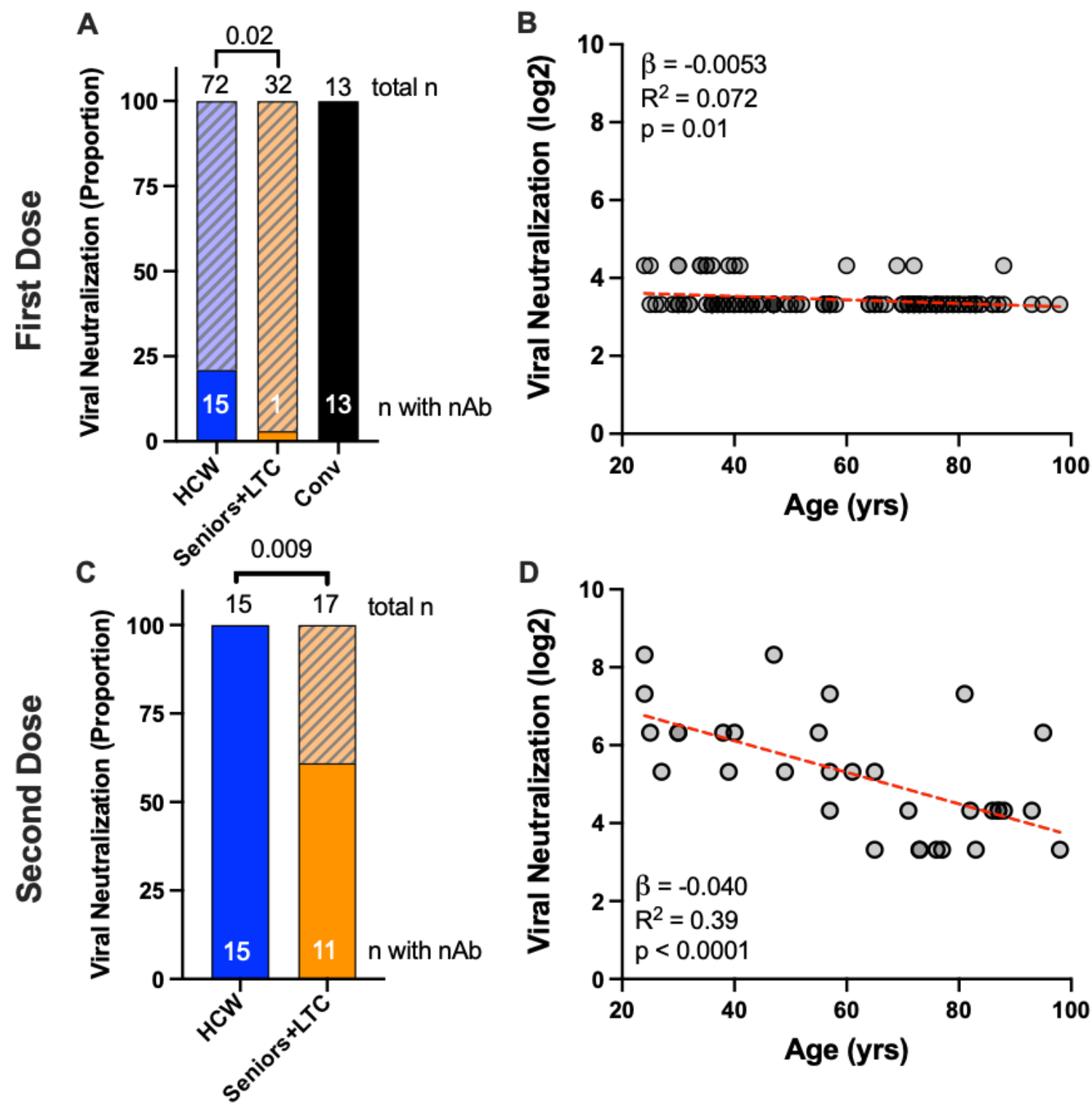

Figure 3: Viral neutralization activity of vaccine-induced antibodies is reduced in older adults. 


\section{Figure 3: Viral neutralization activity of vaccine-induced antibodies is reduced in older}

adults. Panel A: The proportion of participants in each group who displayed any neutralizing activity against live SARS-CoV-2 (USA-WA1/2020 strain) are shown as the solid part of each histogram, where COVID-19 naive HCW and Seniors+LTC are shown in blue and orange respectively, and convalescent participants (Conv) are shown in black. Total Ns in each group are shown above each bar, with the $\mathrm{N}$ of participants displaying neutralizing activity shown within the bar. P-values computed using Fisher's exact test. Panel B: Same data as the HCW and Seniors+LTC groups shown in panel A, but plotted by age, and where neutralization is reported as the reciprocal $\log 2$ dilution value. Samples that displayed neutralization in fewer than three wells at a 1/20 dilution were coded as having a reciprocal dilution factor of 10 (3.32 $\log 2)$. Statistics computed using ordinary least-squares regression. Panels $C, D$ : Same as A and B, but for neutralization responses after two doses of mRNA vaccine in a subset of participants. 
A

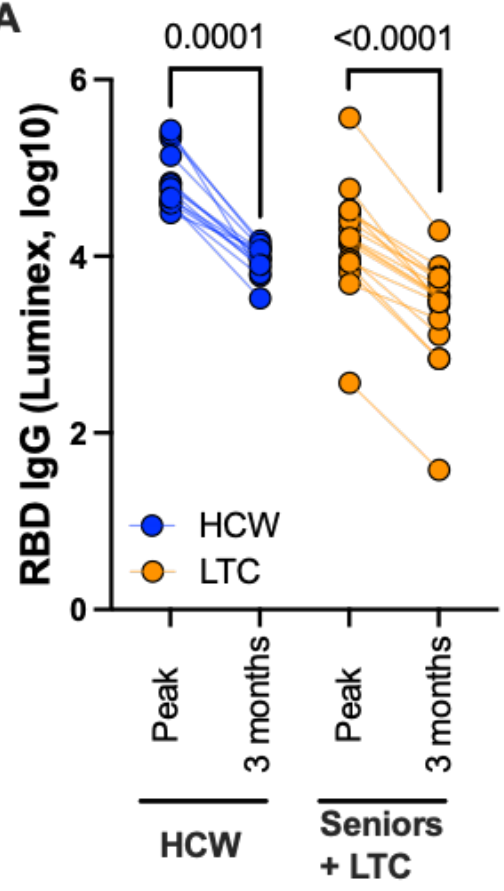

B

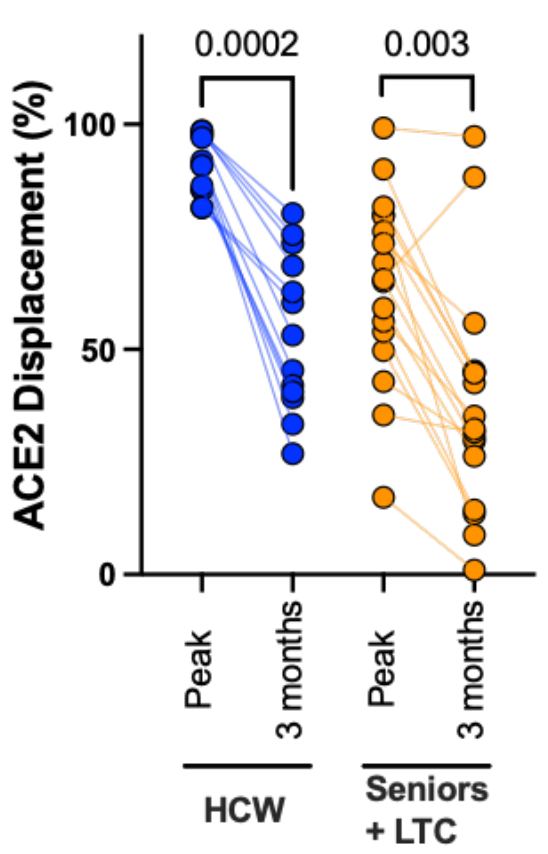

C

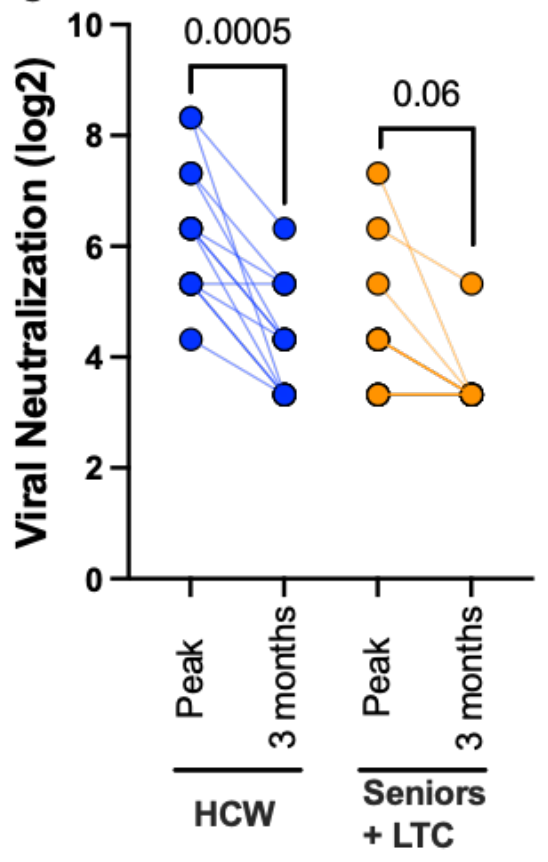

Figure 4: Waning of antibody responses after two doses of mRNA vaccine.

Figure 4: Waning of antibody responses after two doses of mRNA vaccine. Panel A: Binding IgG responses to spike RBD, measured by Luminex ELISA, one month following the second vaccine dose (peak) and three months after this dose (3 months) in a subset of HCW (blue circles) and individuals living in long-term care or assisted living facilities (LTC; orange) who were COVID-19 naive at study entry. P-values computed using the Wilcoxon paired test. Panel $B$ : ACE2 competition assay results, measured by Luminex ELISA, in the same individuals.

Panel C: Virus neutralization assay results, displayed as the reciprocal $\log 2$ plasma dilution, in the same individuals. Note that some values are superimposed. 

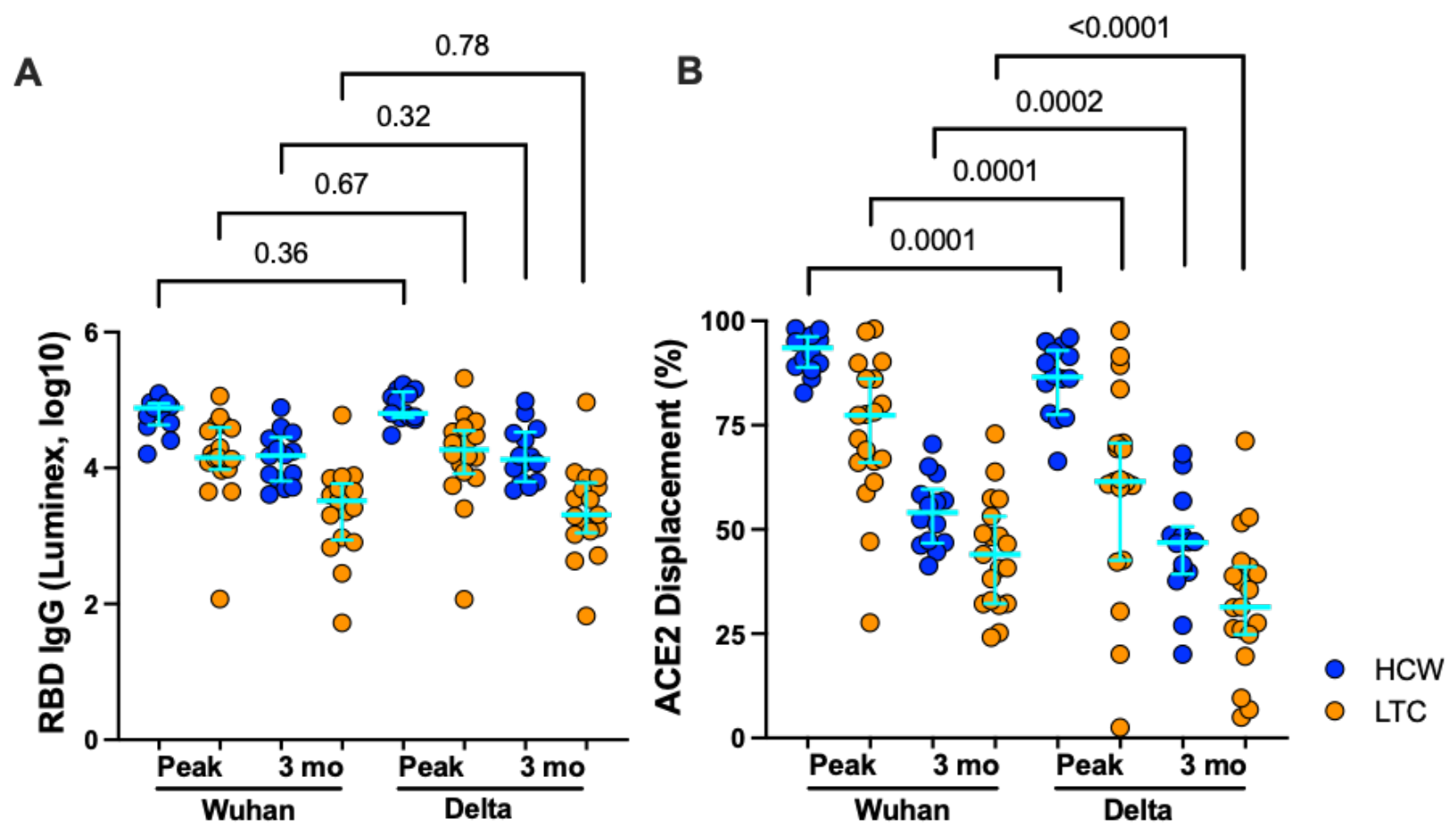

\section{Figure 5: Antibody responses against the Delta variant after two doses of mRNA vaccine.}

Figure 5: Antibody responses against the Delta variant after two doses of $m R N A$ vaccine.

Panel A: Binding IgG antibody responses to spike RBD from the original Wuhan strain and the Delta variant, measured by Luminex ELISA, one month following the second vaccine dose (peak) and three months after this dose (3 mo) in a subset of HCW (blue circles) and individuals living in long term care or assisted living facilities (LTC; orange) who were COVID-19 naive at study entry. Bars represent median and IQR, though p-values are computed using the Wilcoxon paired test as the measurements are paired. Panel B: ACE2 competition results, measured by Luminex ELISA, in the same individuals. 